\title{
KEIKUTSERTAAN KB PASCAPERSALINAN PADA IBU YANG MENGGUNAKAN JAMINAN PERSALINAN
}

\author{
Desi Widiyanti \\ Politeknik Kesehatan Kementerian Kesehatan Bengkulu, Jurusan Kebidanan, \\ Jalan Indragiri Nomor 03 Padang Harapan Kota Bengkulu \\ widiyanti.desi@gmail.com
}

\begin{abstract}
Abstrac: Using postpartum family planning is very effective in achieving success of national family planning program. Participation in postpartum family planning program of mothers using baby delivery insurance is influenced by several factors. The study was analytic cross-sectional on 100 postpartum mothers who used jampersal at the Kepahiang District General Hospital in Bengkulu Province during the period July to September 2012. Chi square and Fisher's Exact test were used for bivariable analysis and multiple logistic regression for multivariable analysis. The results showed that there was a significant influence to probability value $\mathrm{P}<0.05$ from the knowledge factor $(\mathrm{P}=0.006)$, religion view $(\mathrm{P}=0.001)$, access for information $(\mathrm{P}=0.002)$, health care provider's support $(\mathrm{P}=0.004)$, and husband's support $(\mathrm{P}=0.002)$ for participation of postpartum family planning in women who used jampersal at hospital. Husband's support was the dominant factor in the participation of postpartum family planning and 6.4 times likely to increase the participation of postpartum family planning.
\end{abstract}

Keywords: Postpartum family planning, baby delivery insurance

\begin{abstract}
Abstrak : Penggunaan KB pascapersalinan sangat efektif dalam mewujudkan keberhasilan program KB nasional. Keikutsertaan KB pascapersalinan pada ibu yang menggunakan jampersal dipengaruhi oleh beberapa faktor. Penelitian analitik potong silang pada 100 ibu pascapersalinan yang menggunakan jampersal di Rumah Sakit Umum Daerah Kepahiang Propinsi Bengkulu selama periode Juli-September 2012. Analisis bivariabel menggunakan uji chi kuadrat dan uji Fisher Exact, serta analisis multivariabel dan regresi logistik ganda. Hasil penelitian menunjukkan bahwa terdapat pengaruh yang signifikan dengan batas kemaknaan $\mathrm{P}<0,05$ dari faktor pengetahuan $(\mathrm{P}=0,006)$, pandangan agama $(\mathrm{P}=0,001)$, akses terhadap informasi $(\mathrm{P}=0,002)$, dukungan petugas kesehatan $(\mathrm{P}=0,004)$, dan dukungan suami $(\mathrm{P}=0,002)$ terhadap keikutsertaan $\mathrm{KB}$ pascapersalinan. Dukungan suami merupakan faktor yang dominan dalam keikutsertaan KB pascapersalinan dan berpeluang 6,4 kali untuk meningkatkan keikutsertaan KB pascapersalinan.
\end{abstract}

Kata kunci: Keluarga berencana pascapersalinan, jaminan persalinan

Salah satu permasalahan pembangunan kependudukan di Indonesia adalah masih tingginya angka kelahiran penduduk. Angka kelahiran total (Total Fertility Rate/TFR) tercatat sebesar 2,3 per perempuan usia reproduksi dengan jumlah kelahiran setiap tahunnya sekitar 4 juta. Upaya pemerintah dalam menurunkan laju pertumbuhan penduduk adalah melalui program Keluarga Berencana (KB). Angka pemakaian kontrasepsi (Contraceptive Prevalence Rate/ CPR) sudah meningkat namun belum menunjukkan peningkatan yang berarti, yaitu dari 56,7\% (SDKI 2003) menjadi 57,4\% (SDKI 2007).
Keluarga berencana merupakan suatu program yang bertujuan untuk meningkatkan kesejahteraan keluarga khususnya ibu dan anak. Efektivitas dan keberhasilan program keluarga berencana dapat diwujudkan apabila pengenalan kontrasepsi dilakukan pada saat pascapersalinan. Kementerian Kesehatan Republik Indonesia pada tahun 2011 telah meluncurkan langkah terobosan dengan memberikan jaminan persalinan (jampersal) bagi setiap persalinan di Indonesia sebagai upaya menurunkan AKI dan AKB. Jampersal dimaksudkan untuk menghilangkan hambatan finansial bagi ibu hamil, bersalin, nifas termasuk KB pascapersalinan. 
Pelayanan KB jampersal merupakan pelayanan $\mathrm{KB}$ yang diberikan kepada pengguna jampersal baik di fasilitas pelayanan kesehatan pemerintah maupun fasilitas pelayanan kesehatan swasta yang bertujuan untuk meningkatkan akses, kualitas dan menjamin pelayanan $\mathrm{KB}$ pascapersalinan dan pascakeguguran. Jampersal yang mengikutsertakan pelayanan KB di rumah sakit masih rendah, dari 1.523 rumah sakit pemerintah dan swasta yang melayani paket jampersal hanya $36 \%$ rumah sakit yang memberikan pelayanan bersama pemasangan alat kontrasepsi.

Jampersal di Propinsi Bengkulu mulai dilaksanakan pada bulan Mei 2011. Kabupaten Kepahiang merupakan salah satu kabupaten yang ada di Propinsi Bengkulu dengan jumlah pasangan usia subur yang tidak menggunakan alat kontrasepsi paling tinggi pada tahun 2010. Jumlah persalinan Rumah Sakit Umum Daerah (RSUD) Kepahiang pada tahun 2011 adalah 477 persalinan. Jumlah persalinan yang menggunakan jampersal dimulai dari bulan Juni sampai dengan Desember 2011 adalah 138 persalinan, dan yang menjadi akseptor KB baru MOW 15 orang dan IUD 25 orang dari pelayanan KB pascapersalinan. Dari data tersebut belum semua ibu menggunakan alat kontrasepsi pascapersalinan.

Penelitian Gutierrez dkk, melaporkan ada hubungan antara faktor sosial demografi dengan penerimaan dan penolakan KB pascapersalinan. Penelitian Ekabua dkk, menemukan faktor yang mempengaruhi kebutuhan segera menggunakan KB pascapersalinan adalah usia, paritas, pendidikan, status pernikahan, agama, efek samping kontrasepsi, dukungan suami dan tujuan kesehatan reproduksi. Penelitian Duong dkk, melaporkan faktor suami memberikan pengaruh terhadap penggunaan alat kontrasepsi pascapersalinan.

Penelitian yang dilakukan ini untuk mengetahui faktor-faktor yang berpengaruh terhadap keikutsertaan KB pascapersalinan meliputi pengetahuan, pandangan agama, akses terhadap informasi, dukungan pertugas kesehatan dan dukungan suami. Faktor-fak- tor yang akan diteliti berdasarkan permasalahan yang timbul sebagai penyebab rendahnya pemakaian $\mathrm{KB}$ pascapersalinan.

\section{BAHAN DAN CARA KERJA}

Metode penelitian ini adalah analitik dengan rancangan potong lintang. Subjek penelitian adalah ibu pascapersalinan yang bersalin menggunakan jampersal di Rumah Sakit Umum Daerah Kepahiang. Jumlah subjek adalah 100 responden.

Pengumpulan data dilaksanakan pada bulan Juli sampai dengan September tahun 2012. Jenis data yang dipergunakan adalah data primer dengan instrumen pengumpulan data menggunakan kuesioner. Data yang terkumpul dilakukan analisis menggunakan chi kuadrat, Fisher Exact dan analisis multivariabel dengan regresi logistik ganda.

\section{HASIL}

Tabel 1 Distribusi Variabel yang Berpengaruh terhadap Keikutsertaan KB Pascapersalinan

\begin{tabular}{|c|c|c|}
\hline Variabel & $\begin{array}{c}\text { Frek } \\
(\mathbf{N}=100)\end{array}$ & $\begin{array}{c}\text { Presentasi } \\
(100 \%)\end{array}$ \\
\hline \multicolumn{3}{|l|}{$\begin{array}{l}\text { Keikutsertaan dalam } \\
\text { pascapersalinan }\end{array}$} \\
\hline Ikut serta & 66 & 66,0 \\
\hline Tidak ikut serta & 34 & 34,0 \\
\hline \multicolumn{3}{|l|}{ Pengetahuan } \\
\hline Baik & 26 & 26,0 \\
\hline Cukup & 65 & 65,0 \\
\hline Kurang & 9 & 9,0 \\
\hline \multicolumn{3}{|l|}{ Pandangan Agama } \\
\hline Boleh ber-KB & 94 & 94,0 \\
\hline Melarang ber-KB & 6 & 6,0 \\
\hline \multicolumn{3}{|l|}{ Akses terhadap informasi } \\
\hline Terpapar & 90 & 90,0 \\
\hline Tidak terpapar & 10 & 10,0 \\
\hline \multicolumn{3}{|l|}{ Dukungan petugas kesehatan } \\
\hline Mendukung & 85 & 85,0 \\
\hline Tidak mendukung & 15 & 15,0 \\
\hline \multicolumn{3}{|l|}{ Dukungan suami } \\
\hline Mendukung & 77 & 77,0 \\
\hline Tidak mendukung & 23 & 23,0 \\
\hline
\end{tabular}

Pengaruh keikutsertaan KB pascapersalinan oleh ibu pascapersalinan yang menggunakan jampersal berdasarkan pengetahuan, pandangan agama, akses terhadap informasi, dukungan petugas kesehatan, dan dukungan suami dapat dilihat pada tabel 2 berikut: 
Tabel 2 Pengaruh berbagai Faktor terhadap Keikutsertaan KB Pascapersalinan pada Ibu yang Menggunakan Jaminan Persalinan

\begin{tabular}{|c|c|c|c|c|c|}
\hline \multirow[t]{3}{*}{ Variabel } & \multicolumn{2}{|c|}{$\begin{array}{c}\text { Keikutser- } \\
\text { taan KB } \\
\text { Pasca } \\
\text { persalinan } \\
\end{array}$} & \multirow{2}{*}{ Total } & \multirow[t]{3}{*}{$X^{2}$} & \multirow[t]{3}{*}{$p$} \\
\hline & Ikut & $\begin{array}{c}\text { Tidak } \\
\text { ikut }\end{array}$ & & & \\
\hline & $\mathbf{n}$ & $\mathbf{n}$ & $\mathbf{n}$ & & \\
\hline \multicolumn{6}{|l|}{ Pengetahuan } \\
\hline Baik & 21 & 5 & 26 & 10,22 & 0,006 \\
\hline Cukup & 43 & 22 & 65 & & \\
\hline Kurang & 2 & 7 & 9 & & \\
\hline \multicolumn{6}{|c|}{ Pandangan Agama } \\
\hline Boleh ber-KB & 66 & 28 & 94 & - & $\begin{array}{c}0,001 \\
*\end{array}$ \\
\hline $\begin{array}{l}\text { Melarang ber- } \\
\text { KB }\end{array}$ & 0 & 6 & 6 & & \\
\hline \multicolumn{6}{|c|}{ Akses terhadap informasi } \\
\hline Terpapar & 64 & 26 & 90 & - & $\begin{array}{c}0,002 \\
*\end{array}$ \\
\hline Tidak terpapar & 2 & 8 & 10 & & \\
\hline \multicolumn{6}{|c|}{ Dukungan petugas kesehatan } \\
\hline Mendukung & 61 & 24 & 85 & 8,39 & 0,004 \\
\hline $\begin{array}{l}\text { Tidak } \\
\text { mendukung }\end{array}$ & 5 & 10 & 15 & & \\
\hline \multicolumn{6}{|l|}{ Dukungan suami } \\
\hline Mendukung & 57 & 20 & 77 & 9,61 & 0,002 \\
\hline $\begin{array}{l}\text { Tidak } \\
\text { mendukung }\end{array}$ & 9 & 14 & 23 & & \\
\hline
\end{tabular}

Keterangan : Uji Statistik dengan Chi Kuadrat

*Uji Statistik dengan Fisher Exact

Tabel 2 di atas menunjukkan bahwa terdapat pengaruh yang bermakna terhadap keikutsertaan $\mathrm{KB}$ pascapersalinan oleh ibu yang menggunakan jampersal berdasarkan pengetahuan $(\mathrm{p}=0,006)$, pandangan agama $(\mathrm{p}=0,001)$, akses terhadap informasi $(\mathrm{p}=$ $0,002)$, dukungan petugas kesehatan $(\mathrm{p}=$ $0,004)$, dan dukungan suami $(\mathrm{p}=0,002)$.

Pengaruh secara bersama-sama antara berbagai faktor terhadap keikutsertaan KB pascapersalinan oleh ibu yang menggunakan jampersal dapat dilihat pada tabel 3 berikut.

Tabel 3 menunjukkan bahwa pengetahuan $(\mathrm{p}=0,022)$, dukungan petugas kesehatan $(\mathrm{p}=0,023)$, dan dukungan suami $(\mathrm{p}=0,002)$ berpengaruh terhadap keikutsertaan KB pascapersalinan pada ibu yang menggunakan jampersal. Pengaruh dukungan suami paling besar, hal ini berdasarkan nilai rasio prevalensi (RP) pada variabel dukungan suami merupakan nilai paling besar yaitu 6,38.
Tabel 3 Faktor-Faktor yang berpengaruh terhadap Keikutsertaan KB Pascapersalian pada Ibu yang Menggunakan Jaminan Persalinan di Rumah Sakit

\begin{tabular}{lcccc}
\hline \multicolumn{1}{c}{ Variabel } & $\begin{array}{c}\text { Koef } \\
\boldsymbol{\beta}\end{array}$ & $\begin{array}{c}\text { SE } \\
(\boldsymbol{\beta})\end{array}$ & $\begin{array}{c}\text { Nilai } \\
\mathbf{p}\end{array}$ & $\begin{array}{c}\text { RP }(\mathbf{9 5 \%} \\
\mathbf{C I})\end{array}$ \\
\hline Pengetahuan & 1,329 & 0,580 & 0,022 & 3,78 \\
& & & & $(1,21-11,78)$ \\
$\begin{array}{l}\text { Dukungan } \\
\text { petugas } \\
\text { kesehatan }\end{array}$ & 1,502 & 0,658 & 0,023 & 4,49 \\
& & & & $(1,24-16,31)$ \\
$\begin{array}{l}\text { Dukungan } \\
\text { suami }\end{array}$ & 1,853 & 0,590 & 0,002 & 6,38 \\
Constant & - & 1,918 & - & $(2,01-20,29)$ \\
& 5,907 & & & - \\
\hline
\end{tabular}

Keterangan : Akurasi model 74\%

\section{PEMBAHASAN}

Hasil penelitian yang telah dilakukan berdasarkan analisis bivariabel menunjukkan terdapat pengaruh pengetahuan terhadap keikutsertaan KB pascapersalinan pada ibu yang menggunakan jampersal di rumah sakit. Hasil uji multivariabel diketahui bahwa tingkat pengetahuan 3,78 kali mempengaruhi keikutsertaan $\mathrm{KB}$ pascapersalinan pada ibu yang menggunakan jampersal,semakin tinggi tingkat pengetahuan maka keikutsertaan KB pascapersalinan akan meningkat dan sebaliknya semakin rendah tingkat pengetahuan maka keikutsertaan KB pascapersalinan juga akan rendah.

Pengetahuan merupakan faktor yang sangat penting untuk terbentuknya tindakan seseorang, karena perilaku yang didasari oleh pengetahuan akan lebih langgeng. Hasil penelitian Purba, menunjukkan bahwa semakin tinggi pengetahuan maka pemakaian alat kontrasepsi akan meningkat. Pengetahuan yang baik dapat menjadi dasar yang mempengaruhi pemilihan alat kontrasepsi yang akan digunakan. Hal ini sesuai dengan hasil penelitian Dainah dkk, menyatakan bahwa pengetahuan yang cukup tentang KB pascapersalinan dapat memberdayakan ibu pascapersalinan dalam membuat pilihan dan keputusan untuk menggunakan KB pascapersalinan. Tingkat kemandirian setiap individu yang lebih nyata akan bertahan apabila didasari oleh pengetahuan yang kuat. 
Hasil penelitian yang telah dilakukan ber-dasarkan analisis bivariabel menunjukkan terdapat pengaruh pandangan agama terhadap keikutsertaan $\mathrm{KB}$ pascapersalinan pada ibu yang menggunakan jampersal di rumah sakit. Agama merupakan salah satu faktor yang turut mempengaruhi keberhasilan pelaksanaan program keluarga berencana, baik karena aturan-aturan yang terdapat dalam agama itu sendiri maupun latar belakang sosial budaya dari penganut agama tersebut.

Penelitian Nurmaliah, menunjukkan bahwa nilai agama mempengaruhi keikutsertaan pasangan usia subur dalam program $\mathrm{KB}$, semua agama memperbolehkan program KB sebagai upaya untuk meningkatkan kesejahteraan keluarga terutama menjaga kesehatan ibu dan anak. Dalam program jampersal pemakaian alat kontrasepsi pascapersalinan merupakan suatu hal yang sangat dianjurkan bagi pengguna jampersal. Hal ini seharusnya mendapat perhatian dari rumah sakit untuk mendorong dan menganjurkan setiap ibu yang bersalin dengan jampersal harus mengikuti $\mathrm{KB}$ pascapersalinan karena agama bukan merupakan suatu kendala dalam program $\mathrm{KB}$.

Hasil penelitian yang telah dilakukan berdasarkan analisis bivariabel menunjukkan terdapat pengaruh akses terhadap informasi terhadap keikutsertaan KB pascapersalinan pada ibu yang menggunakan jampersal di rumah sakit. Informasi merupakan proses penyampaian pesan yang disengaja dari sumber penerima dengan tujuan mempengaruhi tingkah laku pihak penerima.

Adanya informasi baru mengenai sesuatu hal akan memberikan landasan kognitif baru bagi terbentuknya sikap seseorang. Hasil penelitian Widyastuti, menyatakan bahwa keterpaparan terhadap media atau informasi merupakan determinan yang mempengaruhi keikutsertaan KB pascapersalinan. Dampak informasi akan sampai pada tahap kognitif apabila ditunjang oleh kondisi ibu akan keterpaparan terhadap informasi.

Hasil penelitian Dainah menunjukkan informasi yang diterima ibu pascapersalinan akan mempengaruhi ibu dalam menentukan kontrasepsi yang akan digunakan. Wanita yang lebih sering terpapar informasi cenderung menggunakan kontrasepsi setelah persalinan.

Hasil penelitian yang telah dilakukan berdasarkan analisis bivariabel menunjukkan terdapat pengaruh dukungan petugas kesehatan terhadap keikutsertaan KB pascapersalinan pada ibu yang menggunakan jampersal di rumah sakit. Hasil uji multivariabel diketahui bahwa dukungan petugas kesehatan 4,49 kali lebih tinggi dalam mempengaruhi keikutsertaan $\mathrm{KB}$ pascapersalinan pada ibu yang menggunakan jampersal.

Petugas kesehatan merupakan salah satu faktor yang ikut mendukung peran serta ibu dalam keikutsertaan KB pascapersalinan. Melalui promosi dan informasi, petugas kesehatan dapat memeberikan pengetahuan dan dukungan kepada ibu pascapersalinan sehingga mendorong untuk cenderung mengubah perilakunya.

Petugas kesehatan sangat banyak berperan dalam tahap akhir pemakaian alat kontrasepsi. Berdasarkan penelitian Purba, terdapat pengaruh dukungan petugas kesehatan terhadap pemakaian alat kontrasepsi. Ibu yang awalnya tidak mengetahui dalam pemakaian KB pascapersalinan akhirnya memutuskan untuk memakai alat kontrasepsi setelah mendapat dorongan maupun anjuran dari petugas kesehatan. Petugas kesehatan harus menginformasikan kepada ibu bahwa dalam program jampersal setiap ibu yang yang bersalin dengan jampersal sangat disarankan untuk menggunakan alat kontrasepsi pascapersalinan.

Hasil penelitian yang telah dilakukan berdasarkan analisis bivariabel menunjukkan terdapat pengaruh dukungan suami terhadap keikutsertaan $\mathrm{KB}$ pascapersalinan pada ibu yang menggunakan jampersal di rumah sakit. Hasil uji multivariabel diketahui bahwa dukungan suami 6,38 kali lebih tinggi dalam mempengaruhi keikutsertaan KB pascapersalinan pada ibu yang menggunakan jampersal.

Dalam program KB pascapersalinan, suami isteri perlu berperan dan bertanggung jawab secara seimbang karena suami isteri merupakan pasangan dalam proses repro- 
duksi yang mempunyai hak reproduksi. Metode kontrasepsi tidak dapat dipakai isteri tanpa kerjasama suami. Keadaan ideal bahwa pasangan suami isteri harus bersama memilih metode kontrasepsi yang terbaik, saling kerjasama dalam pemakaian sehingga segala penghambat bagi perempuan yang tidak ingin hamil untuk menggunakan metode $\mathrm{KB}$ pascapersalinan yang efektif sesuai dengan situasi dirinya dan keluarganya dapat dipenuhi.

Partisipasi suami penting dalam pengambilan keputusan dan izin suami sangat diperlukan karena tanpa adanya dukungan suami dapat menjadi penghambat dalam keikutsertaan KB pascapersalinan. Hasil penelitian Ekabua, menemukan faktor dukungan suami mempengaruhi kebutuhan segera penggunaan $\mathrm{KB}$ pascapersalinan. Hasil pe-

\section{DAFTAR RUJUKAN}

Badan Koordinasi Keluarga Berencana Nasional, 2008. Pertemuan nasional keluarga berencana: evaluasi program keluarga berencana 2008. Jakarta.

2010. Hasil pelaksanaan program KB nasional 2010. Jakarta.

Dainah W, Kariuki, Ntozi J, Rutaremwa G, 2011. Determinants of intention to use contraceptive in postpartum period among first time mother in Nairobi, Kenya. Kampala: Departemen of Population Studies, Makerere University.

Direktorat Kependudukan, Pemberdayaan Perempuan, dan Perlindungan Anak, 2010. Evaluasi pelayanan keluarga berencana bagi masyarakat miskin. Jakarta: Bappenas.

Dinas Kesehatan Propinsi Bengkulu, 2011. Profil Kesehatan Propinsi Bengkulu tahun 2011.

Duong DV, Lee AH, 2005. Contraception within sixmonth postpartum in Rural Vietnam: implication on family planning and maternity service. Eur $\mathrm{J}$ Contarcept Reprod Helath Care.

Ekabua JE, Ekabua KJ, Odisolu P, Iklaki CU, Agan TU, Etokidem AJ, 2010. Factors associated with contraceptive use and initiation of coital activity after childbirth. Dove Press Journal : 85-91.

Gutierrez GR, Vazquez MGG, Vargas LFH, De Leon, ALPP, 2003. Postpartum contraceptive acceptance in Leon, Mexico: a multivariate analysis. Eur J Contracept Reprod Health Care;8(4): 210-6. nelitian Duong, Lee, menyatakan suami memberikan pengaruh terhadap penggunaan alat kontrasepsi pascapersalinan, sebagian kecil wanita menolak memakai alat kontrasepsi pascapersalinan karena tidak mendapat dukungan dari suami.

\section{KESIMPULAN}

Pengetahuan, pandangan agama, akses terhadap informasi, dukungan petugas kesehatan, dan dukungan suami berpengaruh baik terhadap keikutsertaan KB pascapersalinan pada ibu yang menggunakan jaminan persalinan di rumah sakit. Dukungan suami merupakan faktor yang paling berpengaruh dalam meningkatkan keikutsertaan KB pascapersalinan pada ibu yang menggunakan jaminan persalinan di rumah sakit.

Notoatmodjo S, 2010. Ilmu perilaku kesehatan. Jakarta:Rineka Cipta.

Nurmaliah, 2011. Hubungan faktor sosiodemografi dan sosio psikologi dengan keikutsertaan pasangan usia subur dalam program keluarga berencana di Kecamatan Nisam Kabupaten Aceh Utara Provinsi Nagroe Aceh Darussalam (tesis). Medan: Program Pascasarjana IKM USU.

Purba JT, 2008. Faktor-faktor yang mempengaruhi pemakaian alat kontrasepsi pada isteri PUS di Kecamatan Rambah Samo Kabupaten Rokan Hulu Tahun 2008 (tesis). Medan: Program Pascasarjana IKM USU.

Parwieningrum E, 2007. Gender dalam KB/KR. BKKBN.

Rumah Sakit Umum Daerah Kepahiang, 2011. Laporan pelayanan jaminan persalinan tahun 2011.

Septi A, Pribadi U, Suranto, 2012. Evaluasi kebijakan pelayanan badan layanan umum. Divison Governance of Research. JKSG: 3.

Sarwono SW, 2001. Psikologi sosial, cetakan kedua. Jakarta: Balai Pustaka.

Widyastuti L, Saikia US, 2011. Postpartum contraceptive use in Indonesia: recent patterns and determinants. Diunduh 29 Desember 2011. Tersedia dari www.itp-bkkbn.org 